JMIAP

\title{
EVALUASI PELAKSANAAN KOTA LAYAK ANAK DALAM PENYEDIAAN INFRASTRUKTUR (SARANA DAN PRASARANA) RAMAH ANAK DI KOTA PADANG
}

\author{
Nurul Annisa \\ Jurusan Ilmu Administrasi Publik, Fakultas Ilmu Sosial, Universitas Negeri \\ Padang \\ $\underline{\text { Nurulannisa51@gmail.com }}$ \\ Zikri Alhadi, S.IP, MA \\ Jurusan Ilmu Administrasi Publik, Fakultas Ilmu Sosial, Universitas Negeri \\ Padang \\ ianunpzikri@yahoo.co.id
}

\begin{abstract}
ABSTRAK
This research aim to examine how the provision of child friendly infrastructure (facilities and infrastructure) in the city of Pariaman. For this reason, an evaluation is needed to assess the policy,based on William Dunn's theory, there are 6 criteria, effectiveness, efficiency, adequency, flattening,responsiveness and accuracy. And the measure had taken by the government institution on issues of the provision of child friendly infrastructure (facilities and infrastructure) at Pariaman city. This research is qualitative descriptive. Data sources from primary and secondary. Data collection techniques are observation, interview and documentation. Test the validity of data checking through triangulation. The findings problem of field, the provision of child friendly infrastructure Pariaman was good but not maximal. It was seen since the time child friendly was implemented, Pariaman still remains in the middle position.
\end{abstract}

Keywords : Evaluation, Provision of child facilities

\section{Pendahuluan}

Pengembangan Kota Layak Anak (KLA) ialah merupakan salah satu upaya perwujudan Good Governance atau tata kelola pemerintahan yang baik.
Berdasarkan (Peraturan Menteri Pemberdayaan dan Perlindungan Anak Republik Indonesia tentang Panduan Pengembangan Kabupaten/Kota Layak Anak, 2011) menjelaskan Panduan Pengembangan Kabupaten/Kota Layak 


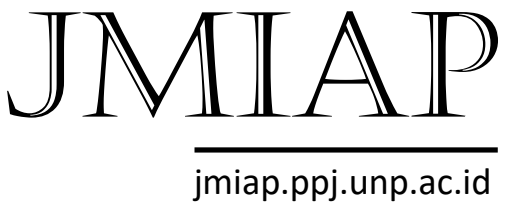

jmiap.ppj.unp.ac.id
Anak, KLA ialah kabupaten/kota yang mempunyai sistem pembangunan berbasis hak anak melalui pengintegrasian komitmen dan sumberdaya pemerintah, masyarakat dan dunia usaha yang terencana secara menyeluruh dan berkelanjutan dalam kebijakan, program dan kegiatan untuk menjamin terpenuhinya hak anak.

Apresiasi pelaksanaan Kota Layak Anak (KLA) di daerah diberikan dengan 5 kategori reward yaitu : (1)Kategori Pratama Kategori Madya (2) Kategori Madya (3) Kategori Nindya (4) Kategori Utama (5) Kategori Kabupaten/Kota Layak Anak. Berikut merupakan tabek kabupaten/kota Sumatera Barat yang mendapatkan penghargaan kabupaten/kota layak anak.

Tabel 1.

\section{Apresiasi Reward Pelaksanaan Kota} Layak Anak Sumatera Barat

Nilai KLA 2018 Sumatera Barat

\begin{tabular}{|c|c|c|}
\hline Kab/kota & $\begin{array}{c}\text { Nilai } \\
\text { Online }\end{array}$ & $\begin{array}{c}\text { Nilai } \\
\text { Verifikasi }\end{array}$ \\
\hline $\begin{array}{c}\text { Kota Padang } \\
(\mathbf{N})\end{array}$ & 972,84 & 786,74 \\
\hline Kota & 922,55 & $\mathbf{5 7 7 , 5 5}$ \\
\hline $\begin{array}{c}\text { Payakumbuh } \\
\text { (P) }\end{array}$ & & \\
\hline $\begin{array}{c}\text { Kab } 50 \text { Kota } \\
\text { (M) }\end{array}$ & 914,79 & 650,39 \\
\hline $\begin{array}{l}\text { Kota Padang } \\
\text { Panjang (M) }\end{array}$ & 906,24 & 605,19 \\
\hline $\begin{array}{c}\text { Kota } \\
\text { Sawahlunto } \\
\text { (N) }\end{array}$ & 900,79 & 856,29 \\
\hline $\begin{array}{c}\text { Kota } \\
\text { Bukittinggi } \\
\text { (P) }\end{array}$ & 900,04 & 568,44 \\
\hline $\begin{array}{c}\text { Kota } \\
\text { Pariaman (M) }\end{array}$ & 884,55 & 641,05 \\
\hline $\begin{array}{c}\text { Kab Tanah } \\
\text { Datar }(\mathbf{P})\end{array}$ & 808,28 & 605,68 \\
\hline $\begin{array}{c}\text { Kota Solok } \\
\text { (P) }\end{array}$ & 806,82 & 580,82 \\
\hline
\end{tabular}

(Sumber: Kementerian Pemberdayaan Perempuan dan Perlindungan Anak, 2018)

Berdasarkan penilaian tersebut, Kota Pariaman merupakan salah satu kota di Sumatera Barat yang meraih predikat menuju Kota Layak Anak, yaitu dengan perolehan nilai verifikasi dari penilaian tim evaluasi independen pusat yaitu dengan perolehan nilai sebanyak 641,05. Yaitu berada pada tingkat madya, dimana dari 18 komponen penilaian, tidak ada angka dibawah $70 \%$ nilai maksimal dan beberapa komponen tertentu harus mencapai angka mutlak.Penilaian ini dilakukan oleh tim pakar anak, akademisi dan praktisi pemerhati hak anak yang berasal dari Kementerian PP-PA, didasarkan pada seberapa besar hak anak yang telah dipenuhi menurut Indikator KLA. Dikeluarkannya (Surat Keputusan Walikota Pariaman nomor 12/463/2010 tentang Pembentukan Gugus Tugas Kota Layak Anak (KLA), 2010) tanggal 26 Januari 2010, tentang pembentukan Gugus Tugas Kota Layak Anak (KLA), membuktikan keseriusan serta perhatian pemerintah Kota Pariaman demi terciptanya Kota Pariaman sebagai Kota Layak Anak. Dalam pelaksanaannya, semenjak KLA diterapkan di Kota Pariaman 8 tahun silam atau pada tahun 2010 yang lalu, Kota Pariaman telah berhasil meraih 5 (lima) kali penghargaan nasional Kota Layak Anak, mulai tahun 2012 tingkat pratama,2013 tingkat madya, 2015 tingkat madya, 2017 tingkat madya dan 2018 tingkat madya. Dalam penelitian ini, peneliti akan meneliti mengenai Evaluasi pelaksanaan Kota Layak Anak dalam Penyediaan Fasilitas Infrastruktur (Sarana dan Prasarana) Ramah Anak di Kota Pariaman. Yang mana fokus nya tentang Penyelenggaraan Kota Layak Anak, maka aspek yang digunakan ialah aspek hasil, yang merujuk pada output dan outcome yang telah dihasilkan. Selama ini, kita lihat Pemerintahan kita lebih 


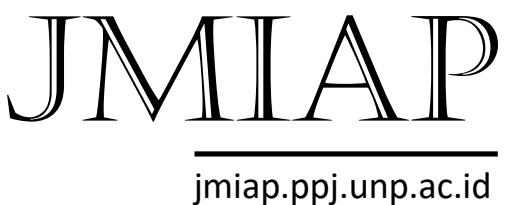

jmiap.ppj.unp.ac.id mementingkan output daripada outcome, padahal kita tahu bahwa masyarakat lebih menginginkan outcome daripada output. Menurut (Hidayat, 2006) Manajemen kinerja Pemerintah yang baik yang beradaptasi dari negara maju yaitu mengacu kepada konsep dalam Government Performance Result and Acts (GPRA). Salah satu ciri manajemen kinerja yang baik ialah proses perencanaan, penganggaran, pengukuran dan pertanggungjawaban penggunaan uang negara harus berdasarkan pada kinerja yang dihasilkan (performance based management). Hal utama yang harus dimiliki ialah memiliki akan kejelasan hasil (outcome) yang dicapainya. Peneliti melihat di Kota Pariaman yakni kinerja Pemerintah daerahnya akan penyelenggaraan KLA masih belum maksimal atau belum sesuai dengan outcome yang diharapkan. Tentunya kita lihat disini Pemerintah Kota Pariaman tetap berada pada tingkat madya hingga saat ini. Penyebabnya yaitu dikarenakan masih ditemui hambatan/kendala dalam upaya penyediaan infrastrukur (sarana dan prasarana) ramah anak dikota Pariaman. Berbagai permasalahan yang menyangkut pemenuhan penyediaan hak anak dikelompokkan berdasarkan setiap klasternya. (1) Klaster hak sipil dan kebebasan, yaitu ditemukan masih minimnya penyediaan fasilitas Informasi Layak Anak (ILA) (2) Klaster keluarga dan Pengasuhan alternatif, belum tersedianya posko tempat pelaporan kekerasan terhadap anak ditingkat desa (3) Klaster kesehatan dasar dan kesejahteraan, minimnya penyediaan fasilitas Kawasan Tanpa Rokok di Kota Pariaman (4) Klaster pendidikan, pemanfaatan waktu luang dan kegiatan seni budaya, minimnya kuantitas dan kualitas Rute Aman Selamat ke dan dari Sekolah (RaSS) (5) Klaster perlindungan khusus, minimnya sarana tempat rehabilitasi bagi korban yang perlu mendapat perlindungan khusus.
Rumusan masalah dalam penelitian ini yaitu:

1) Bagaimana evaluasi pelaksanaan penyediaan infrastruktur (sarana dan prasarana) ramah anak di Kota Pariaman?

2) Apa saja faktor penghambat penyediaan infrastruktur (sarana dan prasarana) ramah anak di Kota Pariaman?

3) Bagaimanakah upaya yang dilakukan Pemerintah dalam penyediaan infrastruktur (sarana dan prasarana) ramah anak di Kota Pariaman?

\section{Tinjauan Kepustakaan}

\section{Evaluasi Kebijakan Publik}

Evaluasi merupakan penilaian kembali terhadap implementasi kebijakan. Tahap ini merupakan proses yang terfokus pada identifikasi hasil pelaksanaan dari implementasi kebijakan. Hal ini berguna untuk mengevaluasi apakah kebijakan tersebut masih layak dipergunakan atau mesti dikoreksi jika ada hambatan-hambatan yang ditemui. Namun, ada juga pandangan yang berpendapat lain, yaitu evaluasi kebijakan yaitu pembelajaran mengenai konsekuensi dari kebijakan publik. hal ini dikemukakan oleh Thomas R.Dye dalam (Hamdi, 2014). Sedangkan Dunn dalam (D.Riant, 2014) Nugroho berpendapat bahwa terdapat 6 (enam) kriteria yang dapat digunakan untuk menilai berhasil atau tidak berhasilnya sebuah kinerja, yaitu : efektivitas, efisiensi, kecukupan, pemerataan, responsivitas dan ketepatan.

\section{Penyediaan Fasilitas Infrastruktur (Sarana dan Prasarana) Ramah Anak di Kota Pariaman}

Fasilitas secara umum dapat diartikan sebagai segala sesuatu atau 


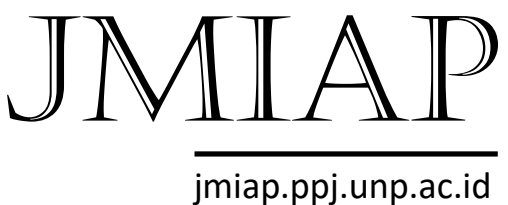

jmiap.ppj.unp.ac.id sebuah alat yang dapat mempermudahkan pekerjaan. Fasilitas infrastruktur (sarana dan prasarana) ramah anak memiliki peran penting dalam mendukung terciptanya Kota Layak Anak (KLA). Fasilitas infrastruktur (sarana dan prasarana) ramah anak ialah segala sesuatu yang dapat dipakai dan merupakan penunjang utama dalam proses menyelenggarakan Kota Layak Anak (KLA).

\section{Metode Penelitian}

Penelitian ini dilakukan di Dinas Pemberdayaan Perempuan dan Perlindungan Anak dan Keluarga Berencana (DP3AKB) Kota Pariaman. Penelitian ini merupakan penelitian deskriptif kualitatif. Pengumpulan data dilakukan dengan teknik wawancara, pengamatan (observasi) dan studi dokumentasi. Penentuan informan penelitian ialah ditentukan secara purposive sampling. Menggunakan teknik keabsahan data yaitu triangulasi sumber data.

\section{Hasil Penelitian Pembahasan}

1. Evaluasi pelaksanaan penyediaan infrastruktur (sarana dan prasarana) ramah anak di Kota Pariaman

Dilihat dari beberapa indikator (N.Dunn, 2000), yaitu sebagai berikut:

1) Efektifitas

Efektifitas selalu berhubungan dengan keterkaitan antara hasil yang diharapkan dengan hasil yang telah tercapai.Pelaksanaan Kota Layak Anak dalam Penyediaan Infrastruktur (Sarana dan Prasarana) Ramah Anak di Kota Pariaman sudah cukup efektif, terlihat dari beragamnya fasilitas yang dibangun Pemko Pariaman yang mengutamakan kepentingan anak seperti pembangunan tempat wisata, taman bermain dan sebagainya.
2) Efisiensi

Efisiensi merupakan suatu usaha yang dilakukan guna mencapai tingkat hasil efektivitas. Penyediaan fasilitas anak di Kota Pariaman sudah mulai berjalan secara efektif. Hal ini terlihat dari ketersedian beragam fasilitas guna menunjang kreativitas anak dalam memanfaatkan waktu luang, seperti forum anak dan taman bermain anak.

3) Kecukupan

Kecukupan merupakan sebuah pengukuran terhadap kinerja yang telah dilakukan Pemerintah. Berkaitan dengan seberapa mampu suatu kebijakan dapat memenuhi kebutuhan masyarakat. Didalam penerapan kebijakan KLA di Kota Pariaman, Pemko Pariaman bekerjasama dengan SKPD terkait guna menyediakan fasilitas ramah anak. Salah satunya dengan menjadikan taman-taman kota atau taman bermain anak yang rekreatif dan edukatif. Hal ini ditetapkan berdasarkan Peraturan Walikota Pariaman No. 03 Tahun 2009 Tentang Penetapan Kawasan Wisata di Kota Pariaman.

4) Pemerataan

Pemerataan mempunyai arti sebagai sebuah keadilan yang diperoleh dan diberikan sesuai sasaran kebijakan. Pelaksanaan kota layak anak dalam penyediaan infrastruktur (sarana dan prasarana) ramah anak di Kota Pariaman belum merata, hal ini terlihat dari hanya beberapa klaster saja yang telah terpenuhi penyediaan infrastruktur(sarana dan prasarana)nya, sebagian lainnya masih ada yang perlu dievaluasi lagi. Seperti dari penyediaan infrastruktur (sarana dan prasarana) dalam penyediaan fasilitas tempat pelayanan bagi anak yang mendapat 
perlindungan khusus dan juga dari segi desa yang mendapat predikat ramah anak, disetiap kecamatan hanya ada baru 1 (satu) desa percontohan, seharusnya semua desa bisa mendapat predikat desa layak anak.

5) Responsivitas

Seberapa jauh kebijakan dapat memuaskan kebutuhan dan mengenali agenda prioritas pelayanan merupakan fungsi dari Responsivitas. Pelaksanaan kota layak anak dalam penyediaan infrastruktur (sarana dan prasarana) ramah anak di Kota Pariaman sudah cukup responsif. Hal ini terlihat dari upaya Pemerintah Kota Pariaman yang terus gencar menjadikan Pariaman sebagai kota layak anak yang mementingkan kepentingan terbaik anak dalam pembangunan.

6) Ketepatan

Ketetapan berkaitan dengan kesesuaian hal yang diharapkan dengan hasil yang ingin dicapai sesuai tujuan. Pelaksanaan kota layak anak dalam penyediaan infrastruktur (sarana dan prasarana) ramah anak di Kota Pariaman telah dilaksanakan sesuai orientasi kebijakan pengembangan KLA. Hal ini terlihat dari pembangunan taman-taman rekreasi ramah anak disepanjang pantai Pariaman yang juga menambah pemasukan bagi APBD Daerah guna menunjang kunjungan wisata di Kota Pariaman.

2. Faktor Penghambat Penyediaan Infrastruktur (Sarana dan Prasana) Ramah Anak di Kota Pariaman

Dalam pelaksanakan Kota Pariaman sebagai Kota Layak Anak dalam penyediaan infrastruktur (sarana dan prasarana) ramah anak, tentunya Pemerintah Kota Pariaman mengalami kendala, seperti:Faktor yang berasal dari dalam lingkungan pelaksana kebijakan (Faktor Internal). Yaitu:Kapasitas Sumber Dana dan Kapasitas Sumber Daya Manusia. Faktor Eksternal, Faktor eksternal merupakan faktor yang berasal dari luar lingkungan pelaksana kebijakan. Yaitu:Kurangnya kesadaran masyarakat.

3. Upaya yang Dilakukan Pemerintah dalam Penyediaan Infrastruktur (Sarana Dan Prasarana) Ramah Anak di Kota Pariaman

Upaya yang dilakukan Pemerintah dalam penyediaan infrastruktur (Sarana dan Prasarana) ramah anak dikota Pariaman yaitu dapat dilihat dari upaya yang dilakukan dalam pemenuhan kebutuhan anak disetiap klasternya. Yaitu : (1) Klaster I Hak Sipil dan Kebebasan, salah satunya melalui penyediaan Fasilitas Informasi Layak Anak (ILA) Upaya yang dilakukan Pemerintah Kota Pariaman yaitu disediakannya perpustakaan dan mobil pustaka keliling serta mobil layanan gratis internet bergerak (mobil internet keliling). (2)Klaster II Lingkungan Keluarga dan Pengasuhan Alternatif, yaitu Pemko Pariaman menyediakan Rumah Singgah Perlindungan Anak (RPSA) Delima yang terletak di Cubadak Air, Pariaman Utara. (3) Klaster III: Kesehatan Dasar dan Kesejahteraan melalui Penyediaan Kawasan Tanpa Rokok (KTR); (4) Klaster IV: Pendidikan, Pemanfaatan Waktu Luang dan Kegiatan Budaya, Yakni melalui Penyediaan Fasilitas untuk Kegiatan Kreatif dan Rekreasi yang Ramah Anak di Luar Sekolah; serta (5) Klaster V: Perlindungan Khusus, yaitu melalui 
Penyediaan fasilitas tempat pelayanan bagi anak yang mendapat perlindungan khusus.

\section{Penutup}

Dari paparan diatas, dapat disimpulkan bahwa: Evaluasi Pelaksanaan Kota Layak Anak dalam Penyediaan Infrastruktur (Sarana dan Prasarana) Ramah Anak di Kota Pariaman dapat dilihat dari beberapa indikator William Dunn, yaitu sebagai berikut: (1) Efektifitas, Pelaksanaan Kota Layak Anak dalam Penyediaan Infrastruktur (Sarana dan Prasarana) Ramah Anak di Kota Pariaman sudah cukup efektif, terlihat dari beragamnya fasilitas yang dibangun Pemko Pariaman yang mengutamakan kepentingan anak; (2) Efisiensi, Usaha dari Pemko Pariaman dalam mengoptimalkan pelaksanaan Kota Layak Anak terkait Penyediaan Infrastruktur (Sarana dan Prasarana) Ramah Anak di Kota Pariaman sudah cukup efisien; (3) Kecukupan, Pelaksanaan penyediaan infrastruktur (sarana dan prasarana) ramah anak diKota Pariaman cukup memuaskan; (4) Pemerataan, pelaksanaan kota layak anak dalam penyediaan infrastruktur (sarana dan prasarana) ramah anak di Kota Pariaman belum merata, hal ini terlihat dari hanya beberapa klaster saja yang telah terpenuhi penyediaan infrastruktur(sarana dan prasarana)nya, sebagian lainnya masih ada yang perlu dievaluasi lagi; (5) Responsivitas, Pelaksanaan kota layak anak dalam penyediaan infrastruktur (sarana dan prasarana) ramah anak di Kota
Pariaman sudah cukup responsif. Terlihat dari keseriusan Pemko dalam merealisasikan kota layak anak melalui sebuah pembangunan yang berkelanjutan yang dapat mengenai masyarakat sasaran; (6) Ketepatan, Penyediaan infrastruktur (sarana dan prasarana) ramah anak diKota Pariaman dalam mewujudkan KLA sepenuhnya bermanfaat bagi masyarakat, terutama anak-anak.

Dari kesimpulan diatas, peneliti memberikan masukan terhadap Pemko Pariaman sebagai pertimbangan kedepannya yaitu: (1)Meningkatkan sinkronisasi pemenuhan hak-hak anak disetiap SKPD terkait seperti Dinas Pemberdayaan Anak Kota Pariaman, Dinas Sosial Kota Pariaman akan urgensinya pelaksanaan kota ramah anak. (2)Menumbuhkan rasa kerjasama yang inisiatif dengan mitra terkait, dalam menambah pemasukan anggaran dana guna mengoptimalkan pembangunan infrastruktur (sarana dan prasarana) ramah anak diKota Pariaman. (3)Meningkatkan SDM yang berkualitas guna mengenali dan memenuhi hak-hak anak serta meningkatkan komunikasi yang intensif dalam mengkoordinir pelaksanaan kebijakan kota layak anak. (4)Melakukan pembangunan rumah singgah atau tempat rehabilitasi untuk menangani pemulihan mental anak yang mengalami trauma mendalam. (5)Melakukan monitoring dan evaluasi terhadap pelaksanaan kota layak anak di Kota Pariaman. 
JMIAP
JURNAL ILMU ADMINISTRASI PUBLIK

Email : jianfis.unp@gmail.com

Vol. 2 No. 1 Maret 2019

\section{DAFTAR PUSTAKA}

D.Riant, N. (2014). Public Policy. Jakarta: PT Elex Media Komputindo.

Hamdi, M. (2014). Kebijakan Publik. Bogor: Ghalia Indonesia.

Hidayat, S. (2006). Evaluasi Implementasi Sistem Akuntabilitas Kinerja Instansi Pemerintah Daerah Kabupaten/Kota. Jurnal Pendayagunaan Aparatur Negara, 6, 124-133.

N.Dunn, W. (2000). Pengantar Analisis
Kebijakan Publik (kedua).

Yogyakarta: Gajah Mada University Press.

Peraturan Menteri Pemberdayaan dan Perlindungan Anak Republik Indonesia tentang Panduan Pengembangan Kabupaten/Kota Layak Anak (2011).

Surat Keputusan Walikota Pariaman nomor 12/463/2010 tentang Pembentukan Gugus Tugas Kota Layak Anak (KLA) (2010). 